\title{
Resilience and Conflict: Evidence from Mali
}

\author{
Marco D'Errico ${ }^{1, * \mathbb{D}}$, Assad Bori ${ }^{2}$ and Ana Paula de la O Campos ${ }^{1}$ \\ 1 Agrifood Economics Division, FAO, 00153 Rome, Italy; Anapaula.delaocampos@fao.org \\ 2 Regional Resilience, Emergency and Rehabilitation Office for West Africa, FAO, Dakar BP N³300 , Senegal; \\ Assad.bori@fao.org \\ * Correspondence: marco.derrico@fao.org
}

Citation: D'Errico, M.; Bori, A.;

Campos, A.P.d.1.O. Resilience and

Conflict: Evidence from Mali.

Sustainability 2021, 13, 10444. https:/ /

doi.org/10.3390/su131810444

Academic Editors: Adesoji O. Adelaja, Justin George Kappiaruparampil and Hossein Azadi

Received: 2 July 2021

Accepted: 14 September 2021

Published: 18 September 2021

Publisher's Note: MDPI stays neutral with regard to jurisdictional claims in published maps and institutional affiliations.

Copyright: (c) 2021 by the authors. Licensee MDPI, Basel, Switzerland. This article is an open access article distributed under the terms and conditions of the Creative Commons Attribution (CC BY) license (https:// creativecommons.org/licenses/by/ $4.0 /)$.

\begin{abstract}
Exploring the contextualized relationship between conflict and household resilience is a key element of policymaking under the Humanitarian and Development nexus. This paper provides new evidence on conflict and resilience from resilience-enhancing projects in Mali's Central Sahel cross-border area. In particular, it explores the presence of determinants of resilience that explains conflict exposure; investigates the adoption of conflict-specific coping mechanisms and explores contextual specificities of local resilience capacity. The findings show that certain types of agricultural households have a higher probability of exposure to conflict, while no evidence of public transfers (e.g., cash transfers) increasing the level of exposure to conflicts is found. The results also show that there are elements which explain the adoption (or lack thereof) of coping mechanisms against conflict: social networks play an essential enabling role, as well as education, the level of food consumption, and to some extent, access to public transfers. Finally, the results suggest that femaleheaded households need more support in order to engage in coping strategies. This paper suggests that resilience-enhancing interventions and analysis require deeper knowledge of the context, paying special attention to the drivers of conflict and coping strategies adopted by households.
\end{abstract}

Keywords: resilience; conflict; food security; quantitative

\section{Introduction}

In recent years, many governments and agencies have adopted a "resilience approach" to foster peacebuilding, as both an alternative response to humanitarian actions and to foster developmental pathways in conflict situations. (A resilience approach has been adopted by several international organizations supporting humanitarian interventions, including donors (e.g., the European Commission (see for more details: https:/ / ec.europa.eu/echo/ what/humanitarian-aid/resilience_en, accessed on 17 September 2021), USAID, DFID, DANIDA, CIDA, Global Affairs Canada) and implementing agencies (e.g., UNICEF (see: https:/ / www.unicef.org/eu/humanitarian-development-nexus, accessed on 17 September 2021), IFAD, WFP, and FAO (see: http:/ / www.fao.org/resilience/home/en/), accessed on 17 September 2021). In this context, understanding the causal transmission mechanismsincluding economic and non-economic channels-between conflict and household resilience is fundamental for the effective design and implementation of humanitariandevelopmental interventions. There is, in fact, evidence that resilience-based approaches have not been too effective in stabilizing conflict-affected contexts, most likely because of some design limitations such as poor context specificity (important examples of conceptual frameworks for resilience measurement that stress the relevance of context are found in [1-3]).

This is complicated by the complex relationships between conflict, conflict response, and resilience, which are highly endogenous. On the one hand, conflict harms household resilience through the destruction of livelihoods, specifically by depleting essential assets, disrupting sources of income generation, or affecting households' labor capacity through wounding or death. Similarly, conflict affects household resilience when it destroys households' access to social services (education, health care, sanitation, and others), 
affecting human capital and well-being; or when it contributes to the dissolution of social networks and mechanisms of solidarity as civilians are displaced [4]. Evidence on the effects of conflict on a number or resilience components are widely available in the literature. For example, Brück et al. [5] finds that conflict is associated with human and financial capital loss, as well as the disruption of technology. Justino [6] finds that civil war leads to the persistence of poverty cycles related to the loss of assets, health and nutrition, education, changes in labor market household allocation decisions, and the loss of individual and household productive capacity. Martin-Shields and Stojetz [7] find a strong relationship between conflict and food insecurity. Bertoni et al. [8] shows that conflict reduces school enrolment and attendance (which are key for fostering household adaptive capacity). Brück et al. [9] demonstrates that conflict deteriorates food security by reducing access to essential services and adaptive capacity, while being partially counterbalanced by increased formal and informal transfers. Singhal [10] finds long-term effects of war, including life shocks and effects on mental health (which are components of resilience and well-being perception).

On the other hand, Ratner et al. [11] considers that resilience could also explain the attitude or willingness of households and individuals to engage with violence and conflicts or pursue peacebuilding coping strategies. Access to resources and livelihoods through functioning levels of cooperation in natural resource management can be an essential element of peacebuilding, conflict prevention, and longer-term social-ecological resilience [11]. However, households, as part of their adaptation and resilience building, can also provoke violence to achieve social change that can be meaningful to those involved [12].

A significant challenge of resilience measurement is the identification of a set of attributes and processes that hold across all conditions along with those that depend on local context [1]. This paper aims to broaden the existing analysis of the relationships of conflict, conflict response, and resilience taking the case of Mali's cross-border area. It does so by investigating which set of resilience determinants are adequate or relevant for understanding of the conflict context and the response mechanisms. The analysis employs the FAO-RIMA's methodological framework (namely, assets base, adaptive capacity, access to essential services, and safety nets) against a unique dataset collected in 2019.

There are three main research questions:

i. What are the critical observable determinants of resilience that affect exposure to household conflict in Central Mali cross-border area? (Research Question 1-RQ1).

ii. What are the observable determinants of resilience that explain the adoption of mechanisms to avoid or increase conflict? (Research Question 2-RQ2).

iii. What is the context specificity that a composite resilience measurement should include in the context of conflict in Mali? (Research Question 3-RQ3).

The remainder of the paper is organized as follows: the next section outlines the paper's conceptual framework and the Malian and Sahelian context. Section 3 presents the data used for this study and the empirical strategy to test the three hypotheses. Section 4 presents the results, and Section 5 concludes.

\section{Literature Review}

\subsection{Livelihoods in the Sahel}

The word Sahel is derived from Arabic, meaning "shore". The area is a vast region in Africa running from the Atlantic Ocean to the Red Sea, extending several hundred kilometers south of the Sahara southward to the coastal forest belt of West Africa and the Central African rainforest. The region experienced one of the most significant climate anomalies globally during the 20th century [13], with high rainfall variability in Niger and parts of Burkina Faso and Mali [14] and low-fertility soils [15]. Over 50 percent of farmland in Sahelian West Africa suffers from poor soil fertility [16].

The semi-arid, harsh natural landscape of the region has shaped the livelihoods of local people over centuries. Everyday livelihoods in the Sahel include pastoral herding of camels and goats, hunting, and crop farming, particularly resistant crops such as sorghum 
and millet. Herders from the Sahel excel in moving cattle over wide extensions of land, with the particularity of livelihoods leading to resilience interventions focusing on mobile populations [17-19]. Because of the devastating Sahelian droughts of 1972-74 and 1984-85 [20,21], the separation of groups based on specific livelihoods (pastoralists, crop farmers) have been gradually disappearing, with these groups increasingly competing for productive resources [21]. Households also supplement their incomes by trading livestock by-products. Illicit businesses such as smuggling and raiding are also typical. Extreme weather conditions, combined with economic crises and armed conflict, have contributed to the worsening of food security of the Sahelian people. The region is one of the few regions globally where the prevalence of undernourishment has been increasing [22] (from 2014 and 2018, the average number of undernourished people increased from 1.0 a million to 1.2 million in Mali [22]).

\subsection{Conflict in the Sahel}

This study covers Mali, one of three countries where the conflict in the Sahel has been escalating over the last ten years. Historical disputes involving pastoralists and farmers have escalated with the use of modern weapons and extremism, with armed conflicts increasing in the Sahel in recent years as a result [19]. From 2019, the increased violence has been concentrated in the bordering regions of these countries, and intercommunal conflict has caused an unprecedented humanitarian crisis in the Sahel and higher levels of food insecurity and malnutrition. The UNHCR (United Nations High Commissioner for Refugees) [23] estimated that more than 2.7 million have been forced to flee their places of origin, and at least 13.4 million need humanitarian aid.

While the conflict in the region has existed for several decades, the conflict escalated after January 2012 when separatist Tuareg rebels launched a rebellion in northern Mali against the government of Amadou Toumani Touré. Months after, Jihadist groups aligned with the Tuareg rebels, taking over several of the country's northern towns. As a response to the escalation of conflict, France launched Operation Serval to fight the jihadists in December 2012, followed by the United Nations' establishment of a peacekeeping mission in April 2013. These contributed to reaching Peace Accords in June 2015; however, violence has continued since, including the bombing of a Bamako luxury hotel. Since 2019, killings have continued in central Mali.

Several studies have focused on the relationship between conflict and resource scarcity, often in the context of climatic shocks. The Sahel, where extreme weather has intensified and has created changes in livelihoods (of pastoralism and crop agriculture) [24], has been the focus of much of this research. A mainstream strand of the literature argues that conflict in the Sahel is largely explained by resource scarcity [25-27], including that caused by desertification due to climate change [28-32]. Yet, these claims continue to be contested [12] as, after all, the Sahel is home to some of the most resilient populations of the world that have faced weather extremes and conflict for decades, if not centuries [12]. Nevertheless, the international community continues to call for resilience approaches to transform resource competition and to strengthen social-ecological resilience as a mechanism for mitigating conflict risk and foster development [33], including in the Sahelian region.

Table 1 summarizes of the evolution of security incidents and fatalities in Mali from August 2012 to August 2019, around the time the data of this study were collected.

Table 1. Evolution of security incidents and losses in Mali between August 2012 and August 2019, Source: ACLED (Armed Conflict Location and Events Data), 2019.

\begin{tabular}{|c|c|c|c|c|c|c|c|c|c|}
\hline \multirow{2}{*}{ Situation } & \multicolumn{8}{|c|}{ Years } & \multirow[t]{2}{*}{ Total } \\
\hline & 2012 & 2013 & 2014 & 2015 & 2016 & 2017 & 2018 & 2019 & \\
\hline Incidents & 61 & 311 & 152 & 178 & 167 & 478 & 754 & 586 & 2687 \\
\hline Fatalities & 83 & 883 & 382 & 428 & 320 & 950 & 1762 & 1336 & \\
\hline
\end{tabular}




\subsection{Resilience in the Humanitarian Support in the Sahel}

Responding to the Sahel crisis has become a global priority, with the United Nations and international donors carrying out several strategies and programs. In this context, understanding the relationships between conflict, conflict response, and resilience matters in order to organize activities on the ground. Amongst these, the regional organization G5 Sahel was formed in 2014 to enhance cooperation for security and development (See https:/ / www.alliance-sahel.org/en/news/the-g5-sahel-enhanced-cooperation-forsecurity-and-development/, accessed on 16 September 2021). Additionally, the United Nations Sahel Support Plan (UNSP) 2018-2030 was launched in 2017 to support actions related to security, governance, development, human rights, and humanitarian aid. The Rome-based Agencies of the UN (FAO, IFAD and WFP) support the RBA action plan for resilience in the Sahel, developed in 2019. Finally, the Sahel Adaptive Social Protection Programme (SASPP) was also launched in 2014 to support households' resilience to climate change (See https: / /www.worldbank.org/en/programs/sahel-adaptive-social-protectionprogram-trust-fund, accessed on 16 September 2021).

One of the goals pursued through the body of programs and projects planned by these regional strategies is to increase household resilience and ensure food security to cope with the growing adverse effects of conflict and climate change (Little and McPeak, 2014). Specifically, building resilience is promoted through multiple interventions, mainly through nutrition programs; livelihood support (including agroecology, pastoralism) or through landscape restoration; integrating Disaster Risk Reduction (DRR) into humanitarian response and development; developing community-based early warning and action system; and through the implementation of cash transfer programs and social protection [34]. This study is situated in one of these resilience projects, called Renforcer la résilience des populations pastorales et agropastorales transfrontalières dans les zones prioritaires $\mathrm{du}$ Sahel, funded by the European Union.

Resilience, in the context of the project, is built through the following mechanisms:

1. Enhancing the availability of information on pastoral resources and movements to guide decisionmakers and agro-pastoralists in their choices of investment strategies, pastoral mobility, economic activities, notably under agro-pastoralist networks (Comités nationaux de transhumance);

2. Capacity building of the technical services of the State, NGOs, and civil society organizations, particularly in cross-border areas, of agro-pastoral practices, social cohesion, agro-pastoral field school approaches, resilience funds, and cash transfers with livelihood interventions (normally called Cash + interventions-FAO 2016);

3. Supporting the improvement and diversification of the livelihoods of agro-pastoral households by promoting inclusive and fair access to inputs and natural resources and the economic benefits of cross-border trade.

\section{Methodology}

\subsection{Data}

The data used in this study collected through a baseline survey of the EU (European Union)-funded project are representative of the areas where the projects were implemented, covering both beneficiary and non-beneficiary communities at the "commune" level in Mali. Households were selected in the following regions (and communes) based on lists of communities generated after the social engineering phase of the project: Mopti (Bankass, Douentza, Koro); Gao (Gao, N'tillit, Tessit, Tin Hamma); Menaka (Alata, Anderamboukane, Inchinane, Tamalate, Tidermene).

The sample was drawn up according to a two-stage stratified plan to ensure municipal representativeness of the information collected. The first stage of sampling was carried out among the beneficiary and non-beneficiary villages of the project. The second stage of sampling consisted of randomly selecting the households within these villages, considering each commune as a stratum. 
Based on the information available from the last National Food and Nutritional Security Survey (ENSAN) in Mali, the sample size was decided to be able to test the hypotheses included in the logical framework of the intervention and considering the food security indicators as outcomes. The estimation of the sample size (see the formula in the Appendix A) employs a given level of confidence (95\%), the expected impact (an increase of at least $40 \%$ of the Food Consumption Score), and an expected nonresponse and attrition rates, both of 5\%. Overall, 1426 households were surveyed during this study, including 598 in Mopti ( 279 beneficiaries and 319 non-beneficiaries), 578 in Gao (370 beneficiaries and 208 non-beneficiaries) and 250 in Ménaka (153 beneficiaries and 97 non-beneficiaries).

The survey instrument was made up of a core questionnaire and specific sections comprising 12 modules (the standard short RIMA questionnaire was contextualized and used as the core questionnaire. These differences aimed to capture specific crops and assets and reflect the specific education system of the country. This core questionnaire was completed by the other modules related to the logical framework of the project, as well as other context-relevant and learning considerations.). Data collection was carried out in June 2019 across the country. The questionnaires covered several aspects of resilience (access to services, assets, social safety nets, demographic characteristics, shocks, and food security), geographic characteristics, conflict exposure, and coping mechanisms. Figure 1 shows additional information about these unique datasets, precisely where data were collected and the sample size for each district for which these datasets are representative. The map also shows the extent of human fatalities recorded within the 12 months preceding the data collection-the most affected areas corresponded to the bordering areas of Mali with Burkina Faso.

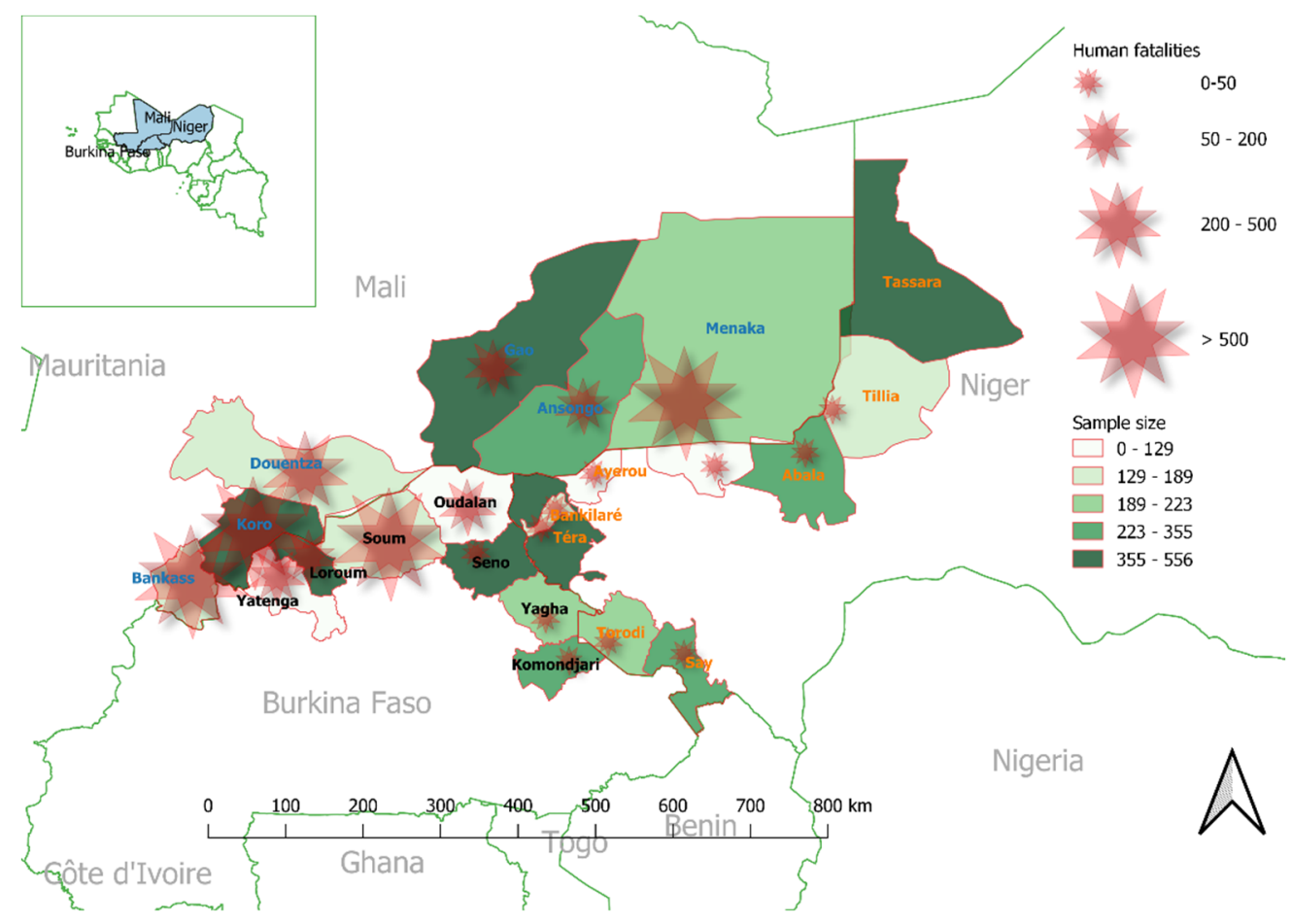

Figure 1. Dataset location, violent incidents (July 2018-June 2019), and sample size (May-June 2019) in the Central Sahel cross-border area, including Mali. Source: authors' elaboration based on the sampling strategy utilized in the household datasets of this study and ACLED (Armed Conflict Location and Events Data) data.

Resilience capacity was measured using the FAO Resilience Index Measurement and Analysis (RIMA) methodology [35]. Variables were created considering the following four pillars: (i) productive and non-productive assets (AST); (ii) access to essential services (ABS); (iii) social safety nets (SSNs); and (iv) the adaptive capacity (AC). The Resilience 
Capacity Index (RCI) is estimated with the Structural Equation Model (SEM) combining the four calculated pillars and two food security indicators (the Food Consumption Score (FCS) and the Food Consumption Expenditure (FE)). RIMA has been widely employed in conflict-specific resilience analysis (see $[9,36]$ in the context of several impact evaluations of resilience projects (e.g., [37,38]); it is also widely adopted as a quantitative measure of resilience. Therefore, the results from this study can be easily compared with earlier work in the humanitarian context.

The other two critical variables of the analysis are those related to the conflict. For "exposure to the conflict", while there are many ways to measure exposure to conflict, this paper builds on previous work $[36,39]$ to detect the "immediate and self-reported response" to violence and conflict by inquiring if and to what extent the household had been exposed to or had witnessed violence. Usually, participation in violence has been investigated through survey experiments or questions about the broad support for violence. This paper follows the latter approach, using a question that was mainly adopted in the literature (More details can be found in von Uexkull et al., 2020).

The survey collected information across a wide range of strategies, as shown in Table 2. These strategies adopted by households are in line with the level of conflict and violence affecting Mali, about 27 percent of households (Figure 1). In terms of coping strategies, 12 percent of households exposed to conflict moved to other areas, and about 21 percent of the households enhanced the security around their homes.

Table 2. Household strategies (\%) in the face of conflict and escalating violence in Mali (Central Sahel cross-border area, June 2019). Source: authors' elaboration.

\begin{tabular}{|c|c|}
\hline Action/Strategy & \\
\hline \multicolumn{2}{|l|}{ Exposure to conflict/violence } \\
\hline Not witnessed (\%)—Not embroiled (a) & 73.14 \\
\hline Not witnessed (\%)—Embroiled (b) & 0.98 \\
\hline Witnessed (\%)—Not embroiled (c) & 10.24 \\
\hline Witnessed (\%)—Embroiled (d) & 15.64 \\
\hline Overall exposure $(\%)(b+c+d)$ & 26.86 \\
\hline \multicolumn{2}{|l|}{ Not try to resolve/mitigate conflict } \\
\hline 01. Done nothing $(\%)$ & 31.30 \\
\hline \multicolumn{2}{|l|}{ Try to resolve/mitigate conflict } \\
\hline 02. Relocated the household (\%) & 11.74 \\
\hline 03. Relocated member of the household (\%) & 6.74 \\
\hline 04. Other persons joined the household (\%) & 5.00 \\
\hline 05. Reduced access to the local market (\%) & 3.91 \\
\hline 06. Became more active in the community (\%) & 1.74 \\
\hline 07. Became less active in the community (\%) & 1.09 \\
\hline 08. Joined the national army or police (\%) & 0.43 \\
\hline 09. Joined the local community police/group (\%) & 1.52 \\
\hline 10. Enhanced security around the home (\%) & 21.09 \\
\hline 11. Joined an armed group (\%) & 5.00 \\
\hline 12. Contacted someone to help solve the conflict (\%) & 8.91 \\
\hline 13. Paid compensation (bribes) to be protected (\%) & 0.43 \\
\hline 14. another mitigation measure (\%) & 1.09 \\
\hline Sample size & 1426 \\
\hline
\end{tabular}


In terms of critical resources (Table 3), most households have improved access to safe water; and most have access to agro-pastoral information (AGPI) (agro-pastoral information refers to all kinds of information received by peasants and herders which help them increase their productivity and reduce the occurrence of agricultural-related risks such as water availability, meteorological or security updates, and pest alerts.). According to the food consumption score (FCS), almost 10 percent of households reported inadequate food consumption in terms of food insecurity.

Table 3. Frequencies distribution of selected qualitative variables. Source: authors' elaboration.

\begin{tabular}{ccc}
\hline Variables & Categories & \% of Households \\
\hline \multirow{2}{*}{ Improved Water Source } & Yes & 86.2 \\
\cline { 2 - 3 } & No & 13.8 \\
\hline \multirow{2}{*}{ Access to Agpi } & Yes & 85.3 \\
\cline { 2 - 3 } & No & 14.7 \\
\hline \multirow{2}{*}{ Food Insecurity (FCS) } & Poor & 9.9 \\
\cline { 2 - 3 } & Borderline & 19.8 \\
\cline { 2 - 3 } & Acceptable & 70.3 \\
\hline & Total & 100.0 \\
\hline
\end{tabular}

\subsection{Methods}

This paper uses a Generalized Linear Model (GLM) to estimate the differential effect of observable factors of resilience on household exposition to conflict and the adoption of mitigation strategies toward conflict. The GLM extends linear modeling to variables that are not normally distributed, allowing a linear model to be related to the response variable via a link function, and allowing the magnitude of the variance of each measurement to be a function of its predicted value [40-42].

The GLM is composed of both link and variance functions. The link function describes how the expectation of the response- the mean of outcome variable $Y$, of household $i$, or $E\left(Y_{i}\right)=\mu_{i}$, depends on the linear predictor $g\left(\mu_{i}\right)=\eta_{i}$.

The variance function describes how the variance, var $\left(Y_{i}\right)$, depends on the mean var $\left(Y_{i}\right)=\varphi V(\mu)$, where the dispersion parameter $\varphi$ is a constant.

Therefore, $Y$ is modeled so that,

$$
E\left(\frac{Y_{i}}{n_{i}}\right)=p_{i}
$$

and the variance is,

$$
\operatorname{Var}\left(\frac{Y_{i}}{n_{i}}\right)=\frac{1}{n_{i}} p_{j}\left(1-p_{j}\right)
$$

So that the variance function is,

$$
V=\left(\mu_{i}\right)=\mu_{i}\left(1-\mu_{i}\right)
$$

and the link function is,

$$
g\left(\mu_{i}\right)=\log i t\left(\mu_{i}\right)=\log \left(\frac{\mu_{i}}{1-\mu_{i}}\right)
$$

The first logit dichotomous model examines the influence of resilience factors on violence and conflict exposure.

$$
S_{i}=G\left(S^{\prime}\right)_{i}=Z_{i} \gamma+u_{1 i}
$$


where:

$S_{i} \quad$ Household's $i$ exposure (1) or not (0) to conflict/insecurity in the last 12 months in Mali.

$Z_{i} \quad$ Matrix of geographic and demographic characteristics, access to agro-pastoral information (AGPI) and resilience pillars (RIMA) of household $i$ in the country.

$\gamma \quad$ Vector of constant parameters in the study area.

$G()$ Logit function.

$u_{1} \quad$ Equation (1) error vector for household $i$.

The second logit dichotomous model aims to determine the effect of resilience factors on the household's attitude toward violence and conflict.

$$
y_{i}=G\left(y^{\prime}\right)_{i}=X_{i} \beta+u_{2 i}
$$

Given that:

$y_{i} \quad$ Adoption (1) or non-adoption (0) of mitigation strategies toward conflicts by household $i$.

$\beta \quad$ Vector of constant parameters in the area of intervention in Mali.

$X_{i} \quad$ Matrix of geographic and demographic characteristics, access to agro-pastoral information (AGPI) and resilience pillars (RIMA) of household $i$.

$G()$ Logit function.

$u_{2} \quad$ Equation (2) error vector for household $i$.

Figure 2 describes this modeling approach.
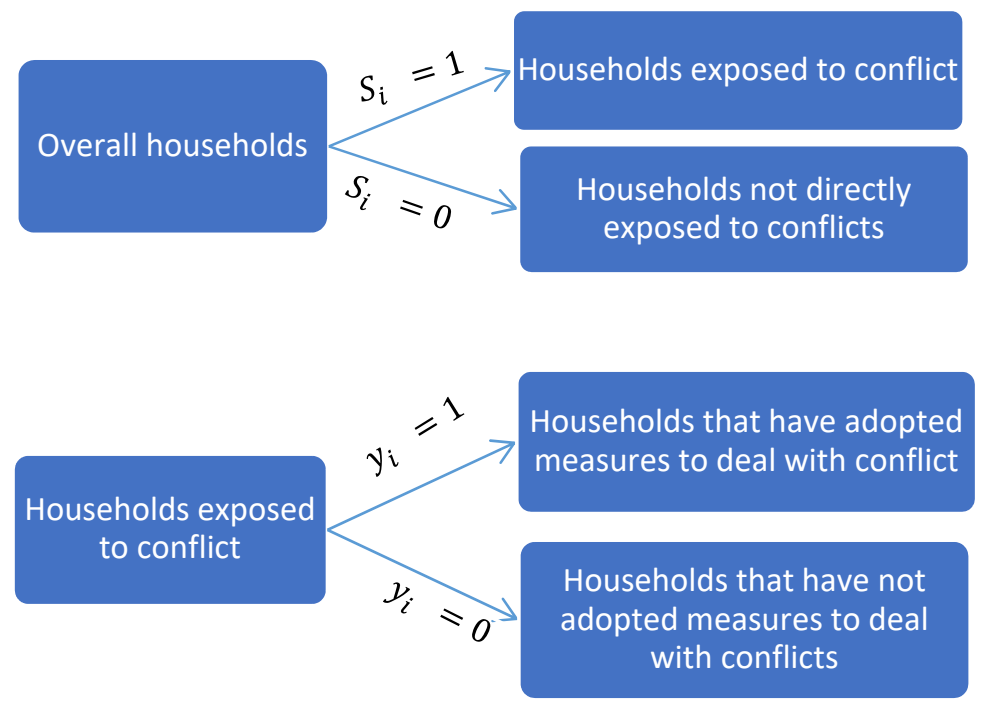

Figure 2. Modeling 1 diagram. Source: authors' elaboration.

\subsection{Robustness Check: Selection Bias Test}

This assumption raises concerns of sample selection bias. Indeed, it is plausible to assume that a response to conflict depends on whether the household is exposed to one (self-selection and, as an outcome, the non-random nature of the data). If this is really the case, (1) and (2) could suffer from selection bias [43].

Consequently, the following Heckman sample selection model was also estimated to check the robustness of modeling 1 [44]. Households' response (mitigation) to conflict is defined such that,

$$
y_{i}=G\left(y^{\prime}\right)_{i}=\left\{\begin{array}{rr}
X_{i} \beta+u_{2 i}, & S_{i}=1 \\
0, & S_{i}=1
\end{array}\right.
$$


where the Heckman selection model (exposure to conflict) is

$$
S_{i}=G\left(S^{\prime}\right)_{i}=Z_{i} \gamma+u_{1 i}
$$

Heckman bias $\rho$ refers to the differences in mitigation strategies in the error terms of both (1) and (2) between exposed and non-exposed households, as follows,

$$
\operatorname{corr}\left(u_{1}, u_{2}\right)=\rho
$$

where:

$S_{i} \quad$ Household's $i$ exposition (1) or not (0) to conflict/insecurity in the last 12 months.

$Z_{i} \quad$ Matrix of geographic, demographic, access to AGPI and resilience pillars (RIMA) of household $i$ in the area of the study.

$\gamma \quad$ Vector of constant parameters.

$u_{1 i} \quad$ Equation (1) error vector for household $i$.

$u_{2 i} \quad$ Equation (2) error vector for household $i$.

$\rho \quad$ Heckman bias.

This second modeling approach based on the test of Heckman bias is described in Figure 3 . The binary variable describing direct exposure to conflict (selection variable $S_{i}$ ) indicates whether any household member has experienced conflict or security incidents (directly involved or witnessed any violent incident/ conflict) in the last twelve months. The binary variable describing the adoption (or not) of mechanisms of prevention, resolution, or mitigation of these conflicts also comes from the conflict survey module. It is defined as "yes" for any household that deployed any strategy but "did nothing".

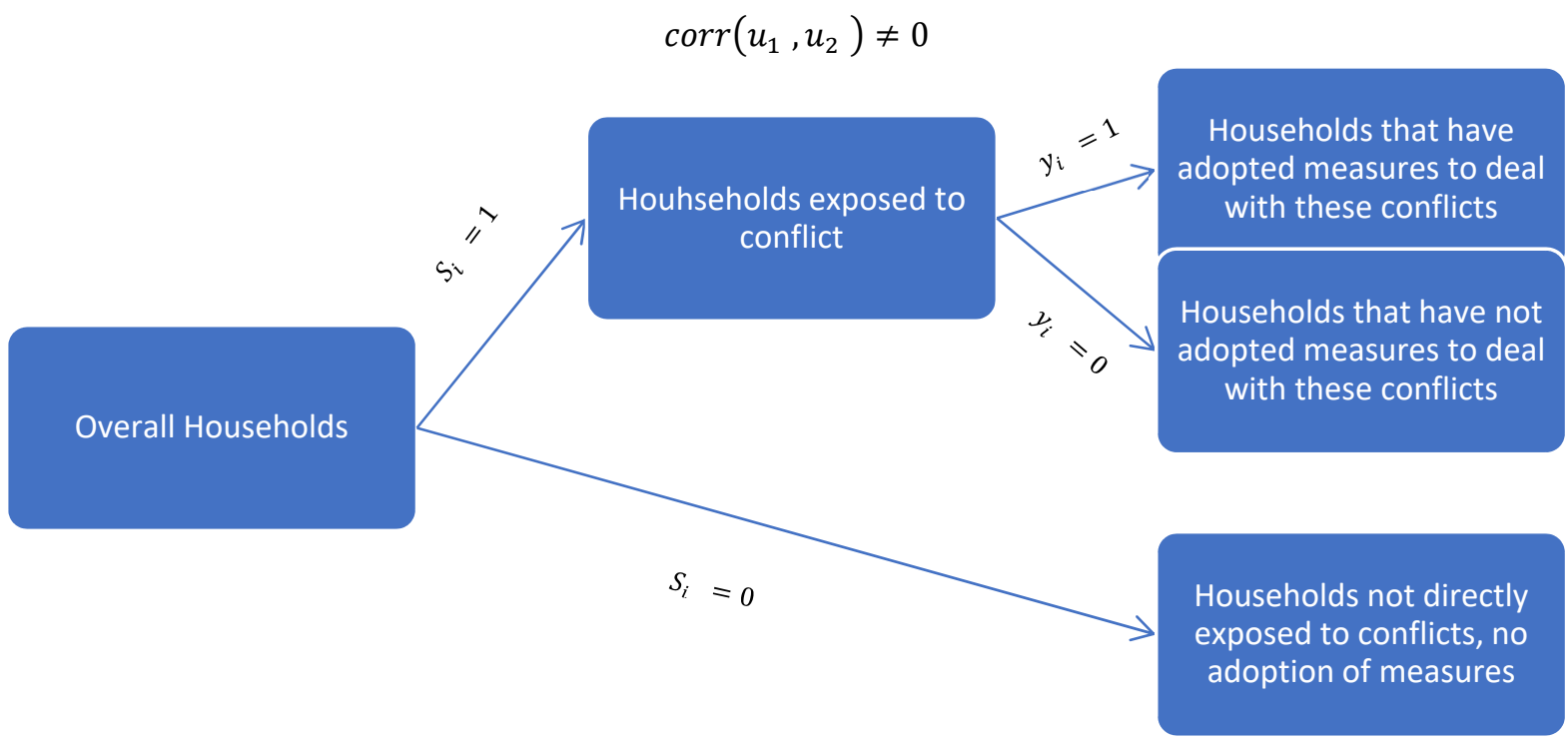

Figure 3. Modeling 2 diagram. Source: authors' elaboration.

These results indicated that there is no selection bias in the model (the two-step estimation consists of first estimating exposure to violence for each country, $j$, while ensuring that there is a selection bias by verifying that the parameters, $\rho$, are not significantly different to 0 , as seen in Table 4 . More precisely, it verifies that $\operatorname{arctg}(\rho))$, and therefore, $\ln (\sigma)$, are significantly different to 0 . This paper employs an indirect estimate, known as the error propagation (delta), by the maximum likelihood method that is applied (StataCorp, College Station, TX, USA, 2015). 
Table 4. Likelihood ratio test of independence of equations. Source: authors' elaboration.

\begin{tabular}{ccc}
\hline Variable Selection & Chi2 Statistic & $p$-Value \\
\hline Backward stepwise & 0.17 & 0.676 \\
\hline Forward stepwise & 2.30 & 0.129 \\
\hline
\end{tabular}

The two-stage specification is not justified. Therefore, this paper opted for a logit model for both exposures to conflict and the adoption of mitigation strategies (Figure 3).

This study has some limitations that must be acknowledged. The first and most important limitation is the limited geographical coverage of the sample; this has immediate consequences on the external validity of the study, which is extremely limited. A second limitation lies with the cross-sectional nature of the datasets, which does not allow one to capture over-time variations. Finally, the limited capacity to include different shocks into this study clearly omits one important threat to resilience capacity.

\section{Results}

\subsection{Resilience Factors Associated with Exposure to Conflict and Violence}

Table 5 shows the results of the GLM on the probability of exposure to conflict over not being exposed to it (the odds ratio) of several factors of resilience, as measured by the RIMA framework (ABS, AST, SSNs, AC, FS). Other factors, including access to agropastoral information (AGPI), location, and demographic characteristics, are also shown. The coefficients reflect the probability of being exposed to conflict and are expressed in terms of odds ratio (OR). An OR higher than 1 indicates that belonging to the associated modality increases the probability of being exposed to conflict compared to the reference (the same applies to the adoption of a mitigating strategy: an OR superior to 1 indicates a higher willingness for associated modality to adopt a mitigating strategy compared to the reference).

Table 5. Influence of different resilience factors on the exposure of households to conflict in Mali (odds ratio). Note: * $p$-value $<0.10 ;{ }^{* *} p$-value $<0.05 ;{ }^{* * *}: p$-value $<0.01$. SE are shown in parenthesis. Source: authors' elaboration.

Access to Basic Services (ABS)

\begin{tabular}{cc} 
Variables & Odds Ratio $^{\mathbf{1}}$ \\
Improved water source & 1.087 \\
& $(0.0822)$ \\
\hline Improved toilet facilities & $0.822^{* *}$ \\
& $(0.0684)$ \\
\hline Electricity cooking/lighting & 1.070 \\
& $(0.0852)$ \\
\hline Distance to water source index & 0.918 \\
& $(0.804)$ \\
\hline Distance to school index & 0.0957 \\
& $(0.142)$ \\
\hline \multirow{2}{*}{ Distance to health center index } & 226.6 \\
& $(1.103)$ \\
\hline Distance to livestock market index & 135.3 \\
& $(1,238)$ \\
\hline Distance to public transport index & $0.00193 *$ \\
& $(0.00623)$ \\
\hline
\end{tabular}


Table 5. Cont.

\begin{tabular}{|c|c|c|}
\hline RIMA & Variables & Odds Ratio $^{1}$ \\
\hline \multirow{8}{*}{ Assets (AST) } & Wealth index & $\begin{array}{c}1.062 \\
(0.243)\end{array}$ \\
\hline & Agricultural assets index & $\begin{array}{l}0.739 * * * \\
(0.0654)\end{array}$ \\
\hline & Use of inputs & $\begin{array}{c}1.400^{* * *} \\
(0.130)\end{array}$ \\
\hline & Tropical livestock unit (TLU) & $\begin{array}{c}0.920 \\
(0.0714)\end{array}$ \\
\hline & Millet production & $\begin{array}{c}1.047 \\
(0.138)\end{array}$ \\
\hline & Sorghum production & $\begin{array}{l}1.191 * * \\
(0.0899)\end{array}$ \\
\hline & Cowpea production & $\begin{array}{l}0.845^{* *} \\
(0.0677)\end{array}$ \\
\hline & Land area & $\begin{array}{c}1.106 \\
(0.164) \\
\end{array}$ \\
\hline \multirow{5}{*}{ Social Safety Nets (SSNs) } & Credit & $\begin{array}{c}0.959 \\
(0.0758) \\
\end{array}$ \\
\hline & Formal transfers & $\begin{array}{c}0.921 \\
(0.0988)\end{array}$ \\
\hline & Informal transfers & $\begin{array}{c}1.217^{* *} \\
(0.112)\end{array}$ \\
\hline & Number of groups & $\begin{array}{c}1.152 \\
(0.103) \\
\end{array}$ \\
\hline & Number of relatives & $\begin{array}{c}1.173 * \\
(0.0963)\end{array}$ \\
\hline \multirow{7}{*}{ Adaptive Capacity (AC) } & Household head literacy & $\begin{array}{c}1.297 \\
(0.299) \\
\end{array}$ \\
\hline & Household head education & $\begin{array}{c}1.146 \\
(0.116) \\
\end{array}$ \\
\hline & Highest education of household & $\begin{array}{c}1.182 \\
(0.129) \\
\end{array}$ \\
\hline & Average education of household & $\begin{array}{l}0.691^{* * *} \\
(0.0834)\end{array}$ \\
\hline & Income diversification & $\begin{array}{c}0.985 \\
(0.0803) \\
\end{array}$ \\
\hline & Dependency ratio & $\begin{array}{c}1.051 \\
(0.0827)\end{array}$ \\
\hline & Crop diversification & $\begin{array}{l}1.240 * \\
(0.150)\end{array}$ \\
\hline \multirow[b]{2}{*}{ Food Security (FS) } & Food expenditures & \\
\hline & Food Consumption Score (FCS) & $\begin{array}{c}1.122 \\
(0.0941)\end{array}$ \\
\hline Agro-Pastoral Information (AGPI) & Access to AGPI & $\begin{array}{c}5.359 * * * \\
(2.060)\end{array}$ \\
\hline
\end{tabular}


Table 5. Cont.

\begin{tabular}{|c|c|c|}
\hline RIMA & Variables & Odds Ratio $^{1}$ \\
\hline \multirow{3}{*}{ Location } & Region of reference & Gao \\
\hline & Menaka & $\begin{array}{c}0.0272 * * * \\
(0.0147)\end{array}$ \\
\hline & Mopti & $\begin{array}{l}0.114^{* * *} \\
(0.0523)\end{array}$ \\
\hline \multirow{5}{*}{ Demographic Characteristics } & Household head gender is male & $\begin{array}{c}1.179 \\
(0.227)\end{array}$ \\
\hline & Girls $<5$ years & $\begin{array}{c}1.154 \\
(0.120)\end{array}$ \\
\hline & Boys < 5 years & $\begin{array}{c}0.857 \\
(0.0853)\end{array}$ \\
\hline & household size & $\begin{array}{c}1.019 \\
(0.0205)\end{array}$ \\
\hline & Constant & $\begin{array}{c}0.0898^{* * *} \\
(0.0519)\end{array}$ \\
\hline \multirow{2}{*}{ Model } & Observations & 1.426 \\
\hline & Pseudo R-squared & 0.19 \\
\hline
\end{tabular}

${ }^{1}$ (Corresponds to the Probability of Being Exposed to Conflict or Violence Relative to Reference, i.e., One Unit Less for the Numerical Variable and to Reference Modality for the Categorical One, Considering All Other Parameters to Be Equal.).

With access to basic services (ABS), another resilience factor considered, the results show that access to sanitation reduces the probability of exposure by 18 percent, while the other factors are not relevant. Households' access to assets (AST) showed more diminishing odds in the exposure to conflict. Having more agricultural assets diminishes the odds of conflict exposure by 26 percent. These results suggest that the better-off households, defined by more agricultural and non-agricultural assets, have a lower probability of being exposed to conflict or violence.

The use of agricultural inputs increases the probability of a household's exposure to conflict by 40 percent. This finding might suggest that those directly engaged in crop agricultural households may be more exposed to conflict, given their fixed location due to their agricultural activities. Sorghum production shows a positive and significant effect on the odds of conflict exposure, while cowpea production has the opposite effect. While there may be no direct link between crop types and conflict, these effects could be associated with location. Sorghum and millet are most common in drier areas of the country, as these crops are more drought-resistant, while cowpeas can also be used to obtain cash quickly.

In terms of supporting mechanisms and safety nets (SSNs), the results show no effects in terms of access of credit or formal transfers (social assistance). However, access to informal transfers by relatives or friends increases the probability of conflict exposure by 22 percent. An additional relative on which the household can rely in the community increases exposure to conflict by 17 percent. However, this result is only statistically significant at the 10 percent level. Finally, membership to one group or association (including farmers' groups, women's support groups, youth groups, business associations, and unions) is not significantly related to increased exposure to conflict. These findings reflect the diverse ways that social networks, in and outside the community (in the case of informal transfers), play a role in exposure to conflict.

In terms of adaptive capacity (AC), the results are consistent with previous findings. In Mali, households with a higher level of education (often correlated with wealthier, better-off households) are less likely to be exposed to conflict, with an odds probability of minus 31 percent. Households with higher crop diversification strategies are more likely to be exposed to conflict than not, increasing odds of conflict exposure by 24 percent. 
Access to AGPI substantially increases the probability of a household being exposed to violence and conflict. This might be associated with the more widespread presence of AGPI in conflict locations. In this region of Mali, people tend to associate around areas better equipped with substantial services, which will ultimately translate into a greater concentration of conflicts.

Finally, this paper finds that exposure to conflicts is geographically heterogeneous. Households living in the Menaka region of Mali show 97 percent lower odds of being exposed to conflict than those in the Gao region, and households in the Mopti region are 89 percent less likely to be exposed to conflict.

\subsection{Resilience Factors Associated with Households' Adoption of Strategies to Face Conflict and Violence}

The second set of findings investigate which resilience factors drive the adoption of strategies towards conflict. In the sample, these adoption strategies are concentrated on enhancing the housing security, moving the entire family or some of its members, or contacting someone else for support. The results are shown in Table 6 below.

Table 6. Influence of the different resilience factors on adopting conflict mitigating strategies in Mali (odds ratio). Note: ${ }^{*} p$-value $<0.10 ;{ }^{* *} p$-value $<0.05 ;{ }^{* * *}: p$-value $<0.01$. Source: authors' elaboration.

\begin{tabular}{|c|c|c|}
\hline RIMA & Variables & Odds Ratio $^{1}$ \\
\hline \multirow{4}{*}{ Access to Basic Services (ABS) } & Improved water source & $\begin{array}{c}1.071 \\
(0.145)\end{array}$ \\
\hline & Improved toilet facilities & $\begin{array}{c}0.825 \\
(0.136)\end{array}$ \\
\hline & Electricity cooking/lighting & $\begin{array}{l}1.366 * \\
(0.232)\end{array}$ \\
\hline & Distance to water source index & $\begin{array}{l}0.0792 \\
(0.146)\end{array}$ \\
\hline \multirow{7}{*}{ Assets (AST) } & Wealth index & $\begin{array}{c}0.757 \\
(0.395)\end{array}$ \\
\hline & Agricultural assets index & $\begin{array}{c}0.939 \\
(0.169)\end{array}$ \\
\hline & Use of inputs & $\begin{array}{c}1.262 \\
(0.223)\end{array}$ \\
\hline & Tropical livestock unit (TLU) & $\begin{array}{c}1.049 \\
(0.146)\end{array}$ \\
\hline & Land area & $\begin{array}{c}0.869 \\
(0.223)\end{array}$ \\
\hline & Sorghum production & $\begin{array}{c}1.144 \\
(0.118)\end{array}$ \\
\hline & Millet production & $\begin{array}{c}0.720 \\
(0.185)\end{array}$ \\
\hline \multirow{5}{*}{ Social Safety Nets (SSNs) } & Credit & $\begin{array}{c}1.195 \\
(0.190)\end{array}$ \\
\hline & Formal transfers & $\begin{array}{l}0.664 * \\
(0.162)\end{array}$ \\
\hline & Informal transfers & $\begin{array}{c}1.104 \\
(0.186)\end{array}$ \\
\hline & Number of relatives & $\begin{array}{c}1.013 \\
(0.164)\end{array}$ \\
\hline & Number of groups & $\begin{array}{l}0.486^{* * *} \\
(0.0903)\end{array}$ \\
\hline
\end{tabular}


Table 6. Cont.

\begin{tabular}{|c|c|c|}
\hline RIMA & Variables & Odds Ratio $^{1}$ \\
\hline \multirow{6}{*}{ Adaptive Capacity (AC) } & Household head literacy & $\begin{array}{c}0.697 \\
(0.281)\end{array}$ \\
\hline & Household head education & $\begin{array}{c}1.134 \\
(0.222)\end{array}$ \\
\hline & Highest education of household & $\begin{array}{c}1.770 * * \\
(0.407)\end{array}$ \\
\hline & Average education of household & $\begin{array}{c}0.697 \\
(0.209)\end{array}$ \\
\hline & Crop diversification & $\begin{array}{c}1.386 \\
(0.284) \\
\end{array}$ \\
\hline & Income diversification & $\begin{array}{c}0.924 \\
(0.137)\end{array}$ \\
\hline \multirow{2}{*}{ Food Security (FS) } & Food Expenditures & $\begin{array}{c}2.125 \text { *** } \\
(0.411)\end{array}$ \\
\hline & Food Consumption Score (FCS) & $\begin{array}{c}0.595^{* * *} \\
(0.101)\end{array}$ \\
\hline Agro-Pastoralist Information (AGPI) & Access to AGPI & $\begin{array}{c}0.385 \\
(0.310)\end{array}$ \\
\hline \multirow{3}{*}{ Location } & Region of reference & Gao \\
\hline & Menaka & $\begin{array}{c}0.456 \\
(0.894)\end{array}$ \\
\hline & Mopti & $\begin{array}{l}0.0495 \\
(0.113) \\
\end{array}$ \\
\hline \multirow{5}{*}{ Demographic Characteristics } & Household head gender is male & $\begin{array}{c}0.387^{* *} \\
(0.147)\end{array}$ \\
\hline & Household size & $\begin{array}{c}1.007 \\
(0.0351)\end{array}$ \\
\hline & Girls $<5$ years & $\begin{array}{c}0.923 \\
(0.188) \\
\end{array}$ \\
\hline & Boys $<5$ years & $\begin{array}{c}0.968 \\
(0.184)\end{array}$ \\
\hline & Constant & $\begin{array}{c}15.37^{* *} \\
(18.11)\end{array}$ \\
\hline \multirow{2}{*}{ Model } & Observations & 383 \\
\hline & Pseudo R-squared & 0.221 \\
\hline
\end{tabular}

\footnotetext{
${ }^{1}$ (Corresponds to the probability of adopting mitigating strategies to conflict or violence relative to the reference, i.e., one unit less for the numerical variable and to the reference modality for the categorical one.).
}

First, these results show that better access to some essential social services (ABS) is to some extent associated with the adoption of strategies to face conflict; in particular, access to electricity is associated with a 37 percent higher probability of adopting mitigating strategies, although this finding is not highly statistically significant. Additionally, asset ownership (AST) in adopting conflict adaptation strategies does not seem to be relevant. These results suggest that wealthier households in terms of agricultural endowments, when exposed, do not adopt new strategies to face conflict.

Regarding social safety nets (SSNs), receiving formal transfers reduces the odds of adopting a strategy to face conflict by 34 percent, although this result is not highly significant. In comparison, the number of groups a household belongs to also reduces the odds of adopting a mitigation strategy by 51 percent, with a strong level of statistical 
significance. This finding might reflect, to some extent, the role of cash transfer programs to cope, but primarily the role of social networks in supporting households when exposed to conflict, as they reduce the need for engaging in new coping strategies. For the role of adaptive capacity (AC), higher education of the household head increases the probability of adopting a conflict adaptation strategy by 77 percent.

As shown by the descriptive statistics, about 30 percent of the households in the sample are affected by poor or borderline food insecurity. The FCS aggregates data on the dietary diversity and frequency of food groups consumed, weighted by their nutritional value. The analysis shows that the higher level of food expenditures doubles the probability of adopting a mitigation strategy, while the food consumption score diminishes the probability of adopting a mitigation strategy by 41 percent. These results suggest that in Mali, being able to consume more food supports the ability of a household to adopt a mitigation strategy; however, households that have access to more nutritious diets may be less likely to adopt a mitigation strategy, as they may be not affected by conflict in the first place.

The results show no geographical heterogeneity in adopting mitigation strategies toward conflict compared to the reference region of Gao. Finally, in terms of demographic characteristics, the results indicate that male-headed households are 61 percent less likely to adopt strategies toward conflict. This finding reflects additional constraints by femaleheaded households in adopting coping mechanisms when exposed to conflict.

\section{Discussion}

In this section, findings from the analysis from the cross-border region of Mali are compared to that of other similar contexts to help derive some conclusions that can help inform the design of resilience approaches in the Malian cross-border area.

Starting with proximity to public transportation and the use of inputs, evidence elsewhere highlights the role of transportation infrastructure in igniting local conflicts (see, for instance [45-48]). This is not the case in the area studied, as no evidence on the proximity to public transportation is found. On the other hand, the extensive use of agricultural inputs, along with access to agro-pastoral information (AGPI) increases the possibility of conflict in the areas studied. In the literature, there is moderate evidence that the extensive use of agricultural inputs is associated with an increase in conflicts. The effect of agricultural inputs is often found in relation to land tenure, which is often a source of conflict [49,50] (land regulation is also crucial in resolving farmer-herder conflicts, although sometimes with adverse effects such as the marginalization experienced by pastoralists [51]). Another study [52] shows that on average, higher yields attract conflict, which might be associated with the extensive use of agricultural inputs. Following this logic, combatants can often turn to local agricultural resources for provisions [53]; so, cropland size and yield can increase the frequency of violence against civilians. The findings suggests that conflicts in Mali can be more frequent in places where food is more available. In Mali, militant groups have a pastoral background, living in more desertic, remote areas, where the Central Government's presence and services are minimal. The reallocation of activities towards militant activities may increase the need of these groups to source food from areas with higher agricultural potential.

The study finds that higher exposure to violence is associated with more relatives in Mali but that membership in local groups supports the adoption of mitigation strategies. Similar findings in other contexts also point to the use of social capital during conflicts, as social support networks can supply emotional, informational, and material support [54]. Additionally, the constitution of groups and networks can reflect a form of division in society, inherent to conflict zones, with people finding refuge in their groups and networks and no longer looking to overcome conflict situations. In Mali, both sedentary and nomadic communities used to share water and pasture from common locations; however, these ties were severed in many groups during the war, putting both communities at risk [54,55].

Finally, the results show that the gender of the household head is significantly associated with the adoption of mitigation strategies in this area of Mali. Specific socio-cultural 
explanations could be associated with this finding, including a relatively high share of female-headed households in this area (15.8 percent), but also, the duration of the insecurity situation in the country, and the use of weapons by international forces (see gender-based implications of the use of weapons in [56]).

The results from this study suggest that unique characteristics may exist in this area of Mali that need to be considered while designing resilience-enhancing interventions, especially under conditions of conflict. Suggestions for how to better address several aspects of resilience are made in the conclusions section below.

\section{Conclusions}

Using a unique dataset collected in the context of resilience projects by FAO and its partners in Mali's Central Sahel cross-border area, this paper applied a GLM and logit models to address three research questions: the critical observable determinants of resilience that affect exposure to household conflict in the Mali cross-border area; the observable determinants of resilience that explain the adoption of mechanisms; and the context specificity that a composite resilience measurement should include in the context of conflict in Mali.

In terms of the first research question, this paper shows that wealthier households, reflected by higher agricultural asset endowments and education, are less likely to be exposed to conflict. In contrast, those households more directly involved in agriculture, with higher use of inputs and sorghum production, have a higher probability of exposure. Indeed, the highest effect in terms of drivers of exposure was households' access to AGPI, reflecting both engagements in the agricultural sector and access to information and networks. There is no evidence that external support (e.g., cash transfers) increases exposure to conflict, while households with more relatives to rely on are more exposed. The latter could be a sign of the tighter tribal lines of those households. Finally, households in the Gao region were more exposed to conflict than those in Menaka and Mopti. This finding is in line with the recording of violent incidents by ACLED (Armed Conflict Location and Events Data).

In terms of the second research question, this paper shows that, first, enhancing the home's security was the most adopted strategy once exposed to conflict, followed by moving the entire household or some of its members. Second, a higher level of education, the strength of social networks and, to some extent, access to public transfers such as cash payments, help make the adoption of new coping strategies more likely. Otherwise, female-headed households have a lower probability of adopting new coping strategies, suggesting the need to provide dedicated support to those households.

Concerning the third and final question, these findings indicate that the correlates of exposure to conflict and the adoption of strategies to cope with conflict have a strong local dimension, which is in line with recent findings in the context of resilience $[57,58]$.

The Sahelian states fear the impact of climate change on conflicts. An increase in armed violence is primarily linked to competition over natural resources in rural areas, and climate change has undoubtedly contributed to worsening of the agro-pastoral system in the region. These findings from the cross-border region of Mali suggest that the fight against climate change alone is not enough to support household-level resilience. Efforts must be framed around a broader set of policy measures to regulate access to productive resources, information, and networks.

Methodological recommendations stem from these findings. A measure of resilience in the cross-border of Mali should include questions about social networks, asset wealth, and access to information; in addition, more indicators of potential sources of gender inequality should be included, for example, supporting networks and the provision of food and agricultural inputs. Through a more comprehensive and context-tailored measure of resilience, it might be possible to achieve fine-tuned policies to support disadvantaged groups of the population. 
Other program implications are derived from these results. First, exposure to conflict seems to be higher for specific agricultural households. This finding needs to be confirmed with qualitative fieldwork and program monitoring, as interventions seeking to develop the resilience of households through livelihood support could also increase the probability of conflict exposure. At the same time, the results suggest that long-term investments in education and the enhancement of social cohesion beyond a household's tribe or community could reduce the probability of conflict exposure.

In terms of supporting the resilience of households to cope with exposure to conflict, again, the strengthening of positive support networks and access to social protection in cash, food, productive assets, or community services can enhance the capacities of households to better adapt to conflict, and potentially to help resolve it. Female-headed households need further support in accessing all these interventions. Therefore, projects adopting a "resilience approach" need to ensure that gender inequalities related to wealth, labor capacity, and time poverty, as well as gender-based discrimination, do not affect women's access to support.

Today, an estimated two billion people live in fragile and conflict-affected areas of the world, being exposed to the impact of conflicts and disasters. While conflicts have common trends and characteristics, the international response mechanisms need to better understand the local context. The concept of resilience is contextual in multiple ways and refers directly to the events, or context, of a person's life [59]. Interventions enhancing resilience in both humanitarian and development contexts can foster the reduction in conflict or limit the exposure to these. The findings of this study suggest that for designing "resilience approaches", not only a comprehensive approach is needed (i.e., addressing various aspects of resilience), but also, the contextualization of that analysis is needed. Finally, a more generic consideration that stems from this paper is the need for both short and long-term interventions. Beyond short-term resilience-enhancing projects, which often focus on deploying rapid response interventions to support humanitarian and emergencies needs, conflict-resolution processes, paired with long-term investments (e.g., long-term investments in education, nutrition, and social cohesion) are fundamental for much desired sustainable development, including that of the Sahel region.

Author Contributions: Conceptualization, M.D., A.B., A.P.d.1.O.C.; methodology, A.B., A.P.d.1.O.C., M.D.; software, A.B.; validation, M.D., A.P.d.1.O.C.; resources, M.D.; writing—original draft preparation, A.B., M.D., A.P.d.1.O.C.; writing-review and editing, A.P.d.l.O.C., M.D.; funding acquisition, M.D. All authors have read and agreed to the published version of the manuscript.

Funding: The data collection of this study was made possible with the collaboration of the European Union.

Institutional Review Board Statement: Informed consent was obtained from all subjects involved in the study.

Informed Consent Statement: Not applicable.

Data Availability Statement: Not applicable.

Acknowledgments: This research paper was developed under the Resilience Measurement program of the Agri-food Economics Division (ESA). The data used in this study were collected to create project baselines of three FAO-led resilience projects in Burkina Faso, Mali, and Niger funded by the Global Network against Food Crises project to "Strengthen the resilience of cross-border pastoral and agro-pastoral populations in priority areas of the Sahel," funded by the European Commission.

Conflicts of Interest: The authors declare no conflict of interest. 


\section{Appendix A}

Table A1. Summary of descriptive statistics for main quantitative variables.

\begin{tabular}{cccccccc}
\hline Pillars & Variables & Min. & Av. & Med. & Max. & S.D. & Range \\
\hline \multirow{2}{*}{ Assets (AST) } & Mali & & & & & \\
& Cattle & 0 & 7.3 & 0.0 & 80 & 11.010 & 80 \\
\cline { 2 - 7 } & Land area (Ha) & 0 & 2.4 & 1.0 & 22 & 3.145 & 22 \\
\hline \multirow{2}{*}{ Social Safety-nets (SSN) } & Credit (FCFA) & 0 & $64,917.6$ & $25,000.0$ & $1,042,000$ & $161,935.800$ & $1,042,000$ \\
\cline { 2 - 7 } & Formal transfers (FCFA) & 0 & $20,883.8$ & 0.0 & $1,000,000$ & $56,145.790$ & $1,000,000$ \\
\cline { 2 - 8 } & Number of groups & 0 & 0.4 & 0.0 & 5 & 0.715 & 5 \\
\hline \multirow{2}{*}{ Adaptive Capacity (A.C.) } & Highest education of household & 0 & 1.8 & 0.0 & 17 & 3.357 & 17 \\
\cline { 2 - 8 } & Crop diversification & 0 & 1.2 & 1.0 & 20 & 1.255 & 20 \\
\hline Food Security (FS) & Food Expenditures (FCFA) & 0 & $26,547.9$ & $10,500.0$ & 760,003 & $52,710.480$ & 760,003 \\
\hline
\end{tabular}

\section{Appendix B. Sample Size Calculation}

Notations

Let the following be:

- $\quad N_{i}$, the number of beneficiaries in strata $I$;

- $\quad n_{i 1}$ et $n_{i 2}$, sample sizes (non-corrected from finite population consideration) of beneficiaries A and non-beneficiaries B groups within strata $i$;

- $\quad k=\frac{n_{i 1}}{n_{i 2}}$, the proportionality coefficient between beneficiaries and non-beneficiaries frequencies;

- $\quad P_{1}$ et $P_{2}$, the proportion of households whose Food Consumption Score (FCS/SCA) is poor or limited, respectively, before and after the project;

- $\varepsilon=P_{1}-P_{2}$, the expected variation of these proportions after the intervention;

- $n_{2}$, the beneficiary sample size without finite population correction;

- $\quad n_{i 2^{\prime}}$, minimum sample size (corrected for the finite parent population, non-response and attrition) necessary to ass $(\varepsilon)$;

- $\quad \alpha$, Type 1 error;

- $\beta$, Type 2 error;

- $s$, attrition rate over the implementation period;

- $a$, the non-response rate.

- $n_{i g}$,household sample per cluster in each strata $i$.

We tried to test the following hypothesis:

$$
H_{0}: \varepsilon \leq 0 \text { and } H_{1}: \varepsilon>0
$$

Beneficiaries group

The relationship between $n_{i 1}$ and $n_{i 2^{\prime}}$ is as follows:

$$
\begin{array}{r}
n_{i 2}=D \times\left(Z_{\alpha}+Z_{1-\beta}\right) \times \frac{\left(P_{1}\left(1-P_{1}\right)+P_{2}\left(1-P_{2}\right)\right)}{\left(P_{2}-P_{1}\right)^{2}} \times\left(1+\frac{1}{k}\right) \\
n_{i 2}^{\prime}=D \times \frac{\left(P_{1}\left(1-P_{1}\right)+P_{2}\left(1-P_{2}\right)\right)}{\left(P_{2}-P_{1}\right)^{2}} \times \frac{\left(Z_{\alpha}+Z_{1-\beta}\right)}{(1-a-s)} \times \frac{\left(N-n_{2}\right)}{(N-1)} \times\left(1+\frac{1}{k}\right)=\frac{n_{i 2}}{(1-a-s)} \times \frac{\left(N-n_{2}\right)}{(N-1)}
\end{array}
$$

Comparison Group

The sample size for this group is defined as follows:

$$
n_{1}=k n_{2}^{\prime}
$$


Overall sample

Finally, the formula for the overall sample is shown below.

$$
n=(1+k) n_{2}^{\prime}
$$

\section{References}

1. Constas, M.; Frankenberger, T.; Hoddinott, J. Resilience Measurement Principles. Toward an Agenda for Measurement Design; Technical Series No. 1; The Food Security Information Network (FSIN): Rome, Italy, 2014.

2. Department for International Development (DFID). Defining Disaster Resilience: A DFID Approach Paper; DFID: London, UK, 2011.

3. United States Agency for International Development (USAID). Ethiopia Pastoralist Areas Resilience Improvement and Market Expansion (PRIME) Project Impact Evaluation Baseline Survey Report; Main Report; USAID: Washington, DC, USA, 2014 ; Volume 1.

4. Maxwell, D.; Stites, E.; Robillard, S.; Wagner, M. Conflict and Resilience: A Synthesis of Feinstein International Center Work on Building Resilience and Protecting Livelihoods in Conflict-related Crises; Feinstein International Center, Tufts University: Boston, MA, USA, 2017.

5. Brück, T.; De Groot, O.J.; Bozzoli, C. How many bucks in a bang: On the estimation of the economic costs of conflict. In The Oxford Handbook of the Economics of Peace and Conflict; Garfinkel, M.R., Skaperdas, S., Eds.; Oxford University Press: Oxford, UK, 2012; pp. 252-274.

6. Justino, P. War and poverty. In IDS Working Papers; John Wiley and Sons, Inc.: New York, NY, USA, 2012; Volume 391, pp. 1-29.

7. Martin-Shields, C.P.; Stojetz, W. Food security and conflict: Empirical challenges and future opportunities for research and policymaking on food security and conflict. World Dev. 2019, 119, 150-164. [CrossRef]

8. Bertoni, E.; Di Maio, M.; Molini, V.; Nistico, R. Education is forbidden: The effect of the Boko Haram conflict on education in North-East Nigeria. J. Dev. Econ. 2019, 141, 102249. [CrossRef]

9. Brück, T.; d'Errico, M.; Pietrelli, R. The effects of violent conflict on household resilience and food security: Evidence from the 2014 Gaza conflict. World Dev. 2019, 119, 203-223. [CrossRef]

10. Singhal, S. Early life shocks and mental health: The long-term effect of the war in Vietnam. J. Dev. Econ. 2019, 141, 102244. [CrossRef]

11. Ratner, B.D.; Meinzen-Dick, R.; May, C.; Haglund, E. Resource conflict, collective action, and resilience: An analytical framework. Int. J. Commons 2013, 7, 183-208. [CrossRef]

12. Turner, M.D. Climate change and social resilience: "Adaptive" conflict in the Sahel. In Proceedings of the Berkeley Environmental Politics Workshop, Berkeley, CA, USA, 12 March 2010.

13. Trenberth, K.E.; Jones, P.D.; Ambenje, P.; Bojariu, R.; Easterling, D.; Klein, T.A.; Soden, B. Observations: Surface and atmospheric climate change. In Climate Change 2007: The Physical Science Basis. Contribution of Working Group I to the Fourth Assessment Report of the Intergovernmental Panel on Climate Change; Solomon, S., Qin, D., Manning, M., Chen, Z., Marquis, M., Averyt, K.B., Tignor, M., Miller, H.L., Eds.; Cambridge University Press: Cambridge, UK, 2007; pp. 235-336.

14. Swinton, S.M. Drought survival tactics of subsistence farmers in Niger. Hum. Ecol. 1988, 16, 123-144. [CrossRef]

15. Sendzimir, J.; Magnuzewski, P.; Reij, C.P. Rebuilding resilience in the Sahel: Regreening in the Maradi and Zinder regions of Niger. Ecol. Soc. 2011, 16, 1-29. [CrossRef]

16. Scherr, S.J. Past and present effects of soil degradation. In Soil Degradation-A Threat for Developing Country Food Security by 2020; Scherr, S.J., Ed.; Discussion Paper 27; International Food Policy Research Institute: Washington, DC, USA, 1999 ; pp. 13-30.

17. Alinovi, L.; Heimrich, G.; Russo, L. Beyond Relief: Food Security in Protracted Crises; ITDG Publications/Practical Action Publishing: Warwickshire, UK, 2008.

18. Livestock Emergency Guidelines and Standards (LEGS) Project. Livestock Emergency Guidelines and Standards; Practical Action Publishing: Warwickshire, UK, 2009.

19. Little, D.P.; McPeak, G.J. Resilience and Pastoralism in Africa South of the Saharan, with a Particular Focus on the Horn of Africa and the Sahel, West Africa; Conference Paper 9; International Food Policy Research Institute (IFPRI): Washington, DC, USA, 2014.

20. Adger, N.; Brooks, N. Does global environmental change cause vulnerability to natural disasters February. In Natural Disasters and Development in a Globalizing World; Pelling, M., Ed.; Routledge: London, UK, 2003; Chapter 2; pp. $19-42$.

21. Nyong, A.; Fiki, C. Drought related conflicts, management and resolution in West African Sahel. In Proceedings of the Human Security and Climate Change: An International Workshop, Asker, Norway, 21-23 June 2005.

22. FSIN. Global Report of Food Crisis 2019: Joint Analysis for Better Decision; FSIN: Brussels, Belgium, 2019.

23. UNHCR (United Nations High Commissioner for Refugees). Sahel Crisis Explained. 2021. Available online: https://www. unrefugees.org/news/sahel-crisis-explained (accessed on 16 September 2021).

24. Thébaud, B.; Batterbury, S. Sahel pastoralists: Opportunism, struggle, conflict, and negotiation. A case study from eastern Niger. Glob. Environ. Chang. 2001, 11, 69-78. [CrossRef]

25. Blench, R.M. Aspects of resource conflict in semi-arid Africa. Nat. Resour. Perspect. 1996, 15, 1-8.

26. Homer-Dixon, T.F. Environment, Scarcity, and Violence; Princeton University Press: Princeton, UK, 1999.

27. Bennett, O. Greenwar: Environment and Conflict; Panos Institute: London, UK, 1991. 
28. Gorse, J.E.; Steeds, D.R. Desertification in the Sahelian and Sudanian Zones of West Africa; World Bank Technical Paper no 62; The World Bank: Washington, DC, USA, 1987.

29. Mainguet, M. Desertification: Natural Background and Human Mismanagement; Springer: Berlin/Heidelberg, Germany, 1994.

30. Mortimore, M. Adapting to Drought. Farmers, Famines, and Desertification in West Africa; Cambridge University Press: Cambridge, UK, 1989.

31. Swift, J. Desertification: Narratives, winners, and losers. In The Lie of the Land; Leach, M., Mearns, R., Eds.; International African Institute: London, UK, 1996; pp. 73-90.

32. United Nations Sudano-Sahelian Office. Assessment of Desertification and Drought in the Sudano-Sahelian Region, 1985-1991; United Nations Development Program: New York, NY, USA, 1992.

33. Hellin, J.B.D.; Ratner, B.; Meinzen-Dick, R.; Santiago, R. Increasing social-ecological resilience within small-scale agriculture in conflict-affected Guatemala. Ecol. Soc. 2018, 23, 5. [CrossRef]

34. Gubbels, P. Escaping the Hunger Cycle: Pathway to Resilience in the Sahel; Sahel Working Group: Washington, DC, USA, 2011.

35. FAO. Resilience Index Measurement and Analysis—II (RIMA—II); FAO: Rome, Italy, 2016.

36. Von Uexkull, N.; d'Errico, M.; Jackson, J. Drought, resilience, and support for violence: Household survey evidence from DR Congo. J. Confl. Resolut. 2020, 64, 1994-2021. [CrossRef]

37. D'Errico, M.; Garbero, A.; Letta, M.; Winters, P. Evaluating program impact on resilience: Evidence from Lesotho's Child Grants Programme. J. Dev. Stud. 2020, 56, 2212-2234. [CrossRef]

38. Malik, A.; D’Errico, M.; Omolo, D.; Gichane, B. Building resilience in Somalia; evidence from field data collection. J. Dev. Eff. 2020, 12, 323-340. [CrossRef]

39. Justino, P.; Brück, T.; Verwimp, P. Micro-level dynamics of conflict, violence, and development: A new analytical framework. In $A$ Micro-Level Perspective on the Dynamics of Conflict, Violence, and Development; Justino, P., Brück, T., Verwimp, P., Eds.; University Press: Oxford, UK, 2013; pp. 2-29.

40. Nelder, J.A.; Wedderburn, R.W. Generalized linear models. J. R. Stat. Soc. A 1972, 135, 370-384. [CrossRef]

41. Iswaran, N.; David, F.P. Conflict analysis using Bayesian neural networks and generalized linear models. J. Oper. Res. Soc. 2010, 61,332-341. [CrossRef]

42. Abel, G.J.; Brottrager, M.; Cuaresma, J.C.; Muttarak, R. Climate, conflict, and forced migration. Glob. Environ. Chang. 2019, 54, 239-249. [CrossRef]

43. Heckman, J. The common structure of statistical models of truncation, sample selection, and limited dependent variables, and a simple estimator for such models. In Annals of Economic and Social Measurement; National Bureau of Economic Research: Cambridge, MA, USA, 1973; pp. 475-492.

44. Heckman, J.J. Sample selection bias as a specification error. Econometrica 1979, 47, 153. [CrossRef]

45. Stravers, A.; Chadury, R.; Wahabzada, T.; Findley, M. Innovations for peace and development department of defense Minerva Initiative. In Natural Resources and Violent Conflict in Central Africa; The World Bank: Washington, DC, USA, 2016.

46. Guariso, A.; Rogall, T. Rainfall Inequality, Political Power, and Ethnic Conflict in Africa. LICOS Discussion Paper No. 391.2017. Available online: https:/ / ssrn.com/abstract=2961694 (accessed on 16 September 2021).

47. Unruh, J.; Pritchard, M.; Savage, E.; Wade, C.; Nair, P.; Adenwala, A.; Lee, L.; Malloy, M.; Taner, I.; Frilander, M. Linkages between large-scale infrastructure development and conflict dynamics in East Africa. J. Infrastruct. Dev. 2019, 11, 1-13. [CrossRef]

48. McGuirk, E.; Burke, M. The economic origins of conflict in Africa. J. Political Econ. 2020, 128, 3940-3997. [CrossRef]

49. Soeters, S.; Weesie, R.; Zoomers, A. Agricultural investments and farmer-fulani pastoralist conflict in West African drylands: A Northern Ghanaian case study. Sustainability 2017, 9, 2063. [CrossRef]

50. Rugadya, M.A. Land tenure as a cause of tensions and driver of conflict among mining communities in Karamoja, Uganda: Is secure property rights a solution? Land Use Policy 2020, 94, 104495. [CrossRef]

51. Walwa, W.J. Land use plans in Tanzania: Repertoires of domination or solutions to rising farmer-herder conflicts? J. East. Afr. Stud. 2017, 11, 408-424. [CrossRef]

52. Koren, O. Food abundance and violent conflict in Africa. Am. J. Agric. Econ. 2018, 100, 981-1006. [CrossRef]

53. Koren, O.; Bagozzi, B.E. Living off the land: The connection between cropland, food security, and violence against civilians. J. Peace Res. 2017, 54, 351-364. [CrossRef]

54. Ng, L.C.; Betancourt, T.S. The physical and mental health of female civilians during war. In The Oxford Handbook of Gender and Conflict; Ní Aoláin, F., Cahn, N., Haynes, D.F., Valji, N., Eds.; Oxford University Press: Oxford, UK, 2018; pp. 1-18.

55. El-Bushra, J.; Sahl, I.M.G. Cycles of Violence: Gender Relations and Armed Conflict; ACORD: Nairobi, Kenya; Construction House: London, UK, 2005.

56. Heyns, C.; Borden, T. Unmanned weapons: Looking for the gender dimension. In The Oxford Handbook of Gender and Conflict; Ní Aoláin, F., Cahn, N., Haynes, D.F., Valji, N., Eds.; Oxford University Press: Oxford, UK, 2018; pp. 376-389.

57. Harari, M.; La Ferrara, E. Conflict, climate, and cells: A disaggregated analysis. Rev. Econ. Stat. 2018, 100, 594-608. [CrossRef] 
58. Asongu, S.; Tchamyou, V.; Minkoua, J.; Asongu, N.; Tchamyo, N. Fighting terrorism in Africa: Benchmarking policy harmonization. Phys. A Stat. Mech. Its Appl. 2018, 492, 1931-1957. [CrossRef]

59. Riley, J.R.; Masten, A.S. Resilience in context. In Resilience in Children, Families, and Communities; Springer: Boston, MA, USA, 2005; pp. 13-25. 